\title{
Application of sol-gel based sensors to environmental monitoring of Mauméjean stained glass windows housed in two different buildings at downtown Madrid
}

\author{
J. PEÑA-POZA, J. F. CONDE, F. AGUA, M. GARCÍA-HERAS AND M. A. VILLEGAS* \\ Instituto de Historia, Centro de Ciencias Humanas y Sociales, CSIC. \\ Calle Albasanz, 26-28. 28037. Madrid, SPAIN. \\ *Autor para correspondencia: Ma Ángeles Villegas Broncano \\ e-mail: mariangeles.villegas@cchs.csic.es - Teléfono: 916022672 - Fax: 916022971
}

\begin{abstract}
Degradation of historical stained glass windows is mainly caused by acid attack enhanced by humidity and pollutants. Accordingly, their preventive conservation should include environmental evaluation. Mauméjean's stained glass windows (c 1940) of two buildings located at downtown Madrid have been monitored by sol-gel sensors of acidity and temperature. The philosophy was the application of innovative glassy sol-gel sensors to assess the conservation conditions of stained glass windows, i.e. modern materials for preservation of historical materials.

Conservation conditions (environmental acidity and temperature) of restored and non-restored stained glass windows have been recorded throughout 13 months. The main contributing parameter to outdoor acidity is proximity to road traffic, which produces acid species able to diminish two units of $\mathrm{pH}$ with respect to neutral conditions. This acid environment affects both sides of stained glass windows, even in those protected with a glazing system, which allows natural ventilation. Other contributing parameters to increase the air acidity were façade orientation, sensor position, distance to pollutants sources, human interaction and uncontrolled ventilation.
\end{abstract}

Keywords: sol-gel sensors, stained glass windows, acidity, temperature, pollution.

Aplicación de sensores sol-gel para la evaluación ambiental de vidrieras de Mauméjean pertenecientes a dos edificios del centro de Madrid

La degradación de vidrieras históricas se debe fundamentalmente al ataque ácido favorecido por la humedad y los contaminantes. Por tanto, su conservación preventiva debe incluir una evaluación ambiental. Se han evaluado vidrieras de Mauméjean (c 1940) de dos edificios del centro de Madrid mediante sensores sol-gel de acidez y de temperatura. La filosofía consistió en aplicar dichos sensores basados en materiales vítreos para tasar las condiciones de conservación de vidrieras del patrimonio, es decir materiales modernos para la preservación de materiales históricos.

Las condiciones de conservación (acidez ambiental y temperatura) de vidrieras restauradas y no restauradas se han registrado durante 13 meses. El principal parámetro que contribuye a la acidez ambiental es la proximidad del tráfico rodado, que origina especies ácidas capaces de disminuir el $\mathrm{pH}$ dos unidades respecto a la neutralidad. Este ambiente ácido afecta ambas caras de las vidrieras, incluso si están protegidas por acristalamientos que permiten la ventilación natural. Otros parámetros que contribuyen son la orientación de la fachada, la posición del sensor, la distancia a los focos de contaminación, la interacción humana y la ventilación no controlada.

Palabras clave: sensores sol-gel, vidrieras, acidez, temperatura, contaminación.

\section{INTRODUCTION}

The influence of the urban environment is nowadays the main factor affecting the proper conservation of materials from the built heritage [1]. Such impact, independent or synergic with the own characteristics of construction materials and other building elements, determines adverse circumstances in the whole task of preventive conservation of historical and/ or artistic items that are permanently exposed to an urban polluted air. This is the case of stained glass windows, which represents a challenging goal for conservation scientists and architects. In fact, urban pollution is considered one of the most dangerous factors against the conservation of heritage items, even those conserved indoor [2]. Therefore, a careful evaluation of environments and micro-environments should be undertaken with the aim to asses the air quality both indoor and outdoor [3,4].

The conservation of historic stained glass windows have commonly focused on curative rather than preventive issues, as well as on Medieval rather than more recent ensembles from $19^{\text {th }}$ and $20^{\text {th }}$ centuries [5]. Consequently, an important body of knowledge on glass degradation processes has been 
generated $[6,7,8,9]$, while much less attention has been paid to preventive conservation issues, especially those concerned with evaluation and control of environmental conditions to which stained glass windows are subjected [10].

Despite glass is considered a durable and well-resistant material against chemicals and pollutants, stained glass windows have been exposed for centuries to atmospheric weathering and human interaction damages. Among environmental conditions, the synergic effect between relative humidity and gaseous pollutants is probably the factor with a more influence for the conservation of stained glass windows, either for glass or for other of their materials such as lead cames, putties, mortars, and different metallic supporting elements [11,12].

With the exception of potash lime silicate glasses, produced mainly in medieval times, the majority of glasses have a quite elevated chemical durability. However, acid gaseous pollutants such as $\mathrm{SO}_{2}$ or $\mathrm{NO}_{x}$ combined with a high relative humidity may produce the phenomenon so-called acid rain; while in a low relative humidity environment yield the dry acid deposition. Under these environmental conditions, most historic glasses undergo a chemical attack which causes, depending on the degree of aggressiveness, formation of a silica gel layer on the surface, leaching of alkaline ions, precipitation of insoluble salts as a result of corrosion and, finally, formation of pits and craters. As a consequence, historic glasses lose mass, transparency and brightness, while grisailles and other glassy paints may detach, which produce a great deterioration in both the iconographic and the aesthetic value of stained glass windows [13].

The challenge for preventive conservation of historic stained glass windows is, therefore, being able to evaluate carefully the immediate micro-environmental conditions to which they are subjected. Moreover, more than relative humidity, the key variable to be measured must be the environmental acidity that is produced by gaseous pollutants. Based on these requirements, the research team of this paper has been developing innovative optical sensors obtained by the sol-gel chemical process to evaluate the whole acidity of a gaseous environment as the air. These sensors present, among other advantages, accuracy, reliability, fast response, good chemical resistance, small size, low cost and easy handling $[14,15]$. Conventional available acidity sensors are electrodes, which are not able to measure the $\mathrm{pH}$ (acidity/basicity) in gaseous environments and, therefore, are not suitable for measuring the air $\mathrm{pH}$. The novelty of this paper is, accordingly, to challenge the evaluation of micro-environmental conditions of two buildings at downtown Madrid containing ensembles of historic stained glass windows belonging to the Mauméjean workshop. These buildings are the Holy Spirit church and the headquarters of the Spanish National Research Council (CSIC). Evaluation of micro-environmental conditions has been undertaken by innovative optical sensors of acidity and temperature. These latter temperature sensors are also obtained by the sol-gel procedure [16] and have been used as a suitable alternative to conventional thermometers. The program of evaluation using this kind of sensors has been accomplished with the aim of establishing a preventive conservation strategy to adequately preserve this valuable glass legacy for the future.

The Mauméjean workshop was one of the most important manufacturers of stained glass windows in Spain during the late $19^{\text {th }}$ and early $20^{\text {th }}$ centuries. It was founded in 1860 by Jules Mauméjean, a French glassmaker who established a first workshop in Pau (France). In 1897 Jules Mauméjean installed a workshop in Spain, which was passed down later to his two sons, Joseph and Henri. During the first two decades of the $20^{\text {th }}$ century, it experienced a fast growth as a result of the high number of architects who integrated stained glass windows in civil and religious buildings. Consequently, in 1923 the Mauméjean brothers converted the former workshop into the Sociedad Mauméjean Hermanos de Vidriería Artística, S.A., operating in Madrid and many other Spanish and French cities. The production developed by the Mauméjean workshop comprised a wide range of artistic styles, such as Neogothic, Neorenaissance, Neobaroque, Art Nouveau, Art Déco, Symbolism and so on [17]. Between 1939 and 1950 the styles of the Mauméjean workshop were mainly based on two tendencies: the European fascism and a deep national spirit, following the official policy of the Spanish post-Civil War period. The first tendency was soon discarded, while the second one lasted up to 1950 and was based on patterns from the Spanish Habsburg Empire. This style recovers symbolism, the ancient function of stained glass windows which was lost in Art Nouveau and Modernism styles [18].

Stained glass window panels of the Holy Spirit church and the CSIC headquarters were produced between 1942 and 1943. They are representative of the late artistic and technical manufactures of the Mauméjean workshop. The main motifs used for the stained glass windows at the CSIC headquarters were taken from allegories of Sciences and show a classic iconography. Among the whole ensemble, that called the Science Tree, which is the CSIC symbol, can be highlighted as an example of artistic expression as well as perfection in the manufacturing technique. The stained glass windows at the Holy Spirit church were based on a design by Ramón Stolz Viciano. Those panels located at the central nave and the transept show the main saints who studied topics concerned with the Holy Spirit and the seven gifts of the Holy Spirit, while the rose window displays the dream of Solomon alluding to wisdom. From an iconographic point of view, all the stained glass windows can be assigned to a classicism style [19].

\section{MATERIALS AND METHODS}

\subsection{Synthesis of sensors}

The sol-gel procedure is a chemical route to prepare glassy materials, either bulk or as a thin coating [20]. In general, liquid reagents such as alkoxides and alkylalkoxides are the precursors for the most common glass network former $\left(\mathrm{SiO}_{2^{\prime}}\right.$ silica), which is hydrolyzed by water at room temperature under acid catalysis. This stage of colloidal suspension is known as sol. Further polycondensation accomplished between room temperature and $<100{ }^{\circ} \mathrm{C}$ provides a hydrated silica network known as gel. Therefore, a high temperature as that needed for conventional glass melting process is not required. The sol-gel procedure is able to incorporate a wide variety of dopants during the sol (liquid) stage. Functional properties of the final sol-gel glassy material are thus determined by those of the dopant immobilized into the gel network.

For the present acidity sensors the thin sensitive layer is obtained from a sol doped with an organic dye selected on 
the basis of the $\mathrm{pH}$ range to be evaluated from 5 to 8 , since such a range is expected at downtown Madrid, with relatively high levels of pollution due to intense road traffic. This sol is prepared from two solutions: 1) silicon tetraethoxide diluted with absolute ethanol and concentrated $\mathrm{HCl}$ (37 wt. \%), and 2) chlorophenol red in absolute ethanol. Once solution 1 is homogenised after the silicon tetraethoxide hydrolysis, solution 2 is added and stirred for $30 \mathrm{~min}$. Chemically cleaned common glass slides were dipped into the freshly prepared sol and withdrawn at a rate of $1.35 \mathrm{~mm} \mathrm{~s}^{-1}$. The coated slides were dried at room temperature for $30 \mathrm{~min}$, and then thermally treated at $60{ }^{\circ} \mathrm{C}$ in a forced air stove for $72 \mathrm{~h}$ [21]. Once accomplished the heat-treatment, partially densified sensitive coatings were obtained. Further cutting and polishing of the coated area (250-450 $\mathrm{nm}$ in thickness) provided sensor slabs of $2.5 \times 3.5 \mathrm{~cm}$ in size.

Temperature sensors are also prepared from a sol, even though in this case the sensitive phase consists in a coordination complex containing $\mathrm{Co}^{2+}$ as central cation, which is incorporated into the prehydrolysed silicon tetraethoxide solution. The freshly prepared sol is then cast into spectrophotometric cuvettes of polymeric material, which are immediately sealed with a chemically inert cap for longer usefulness. Finally, sol containing cuvettes are
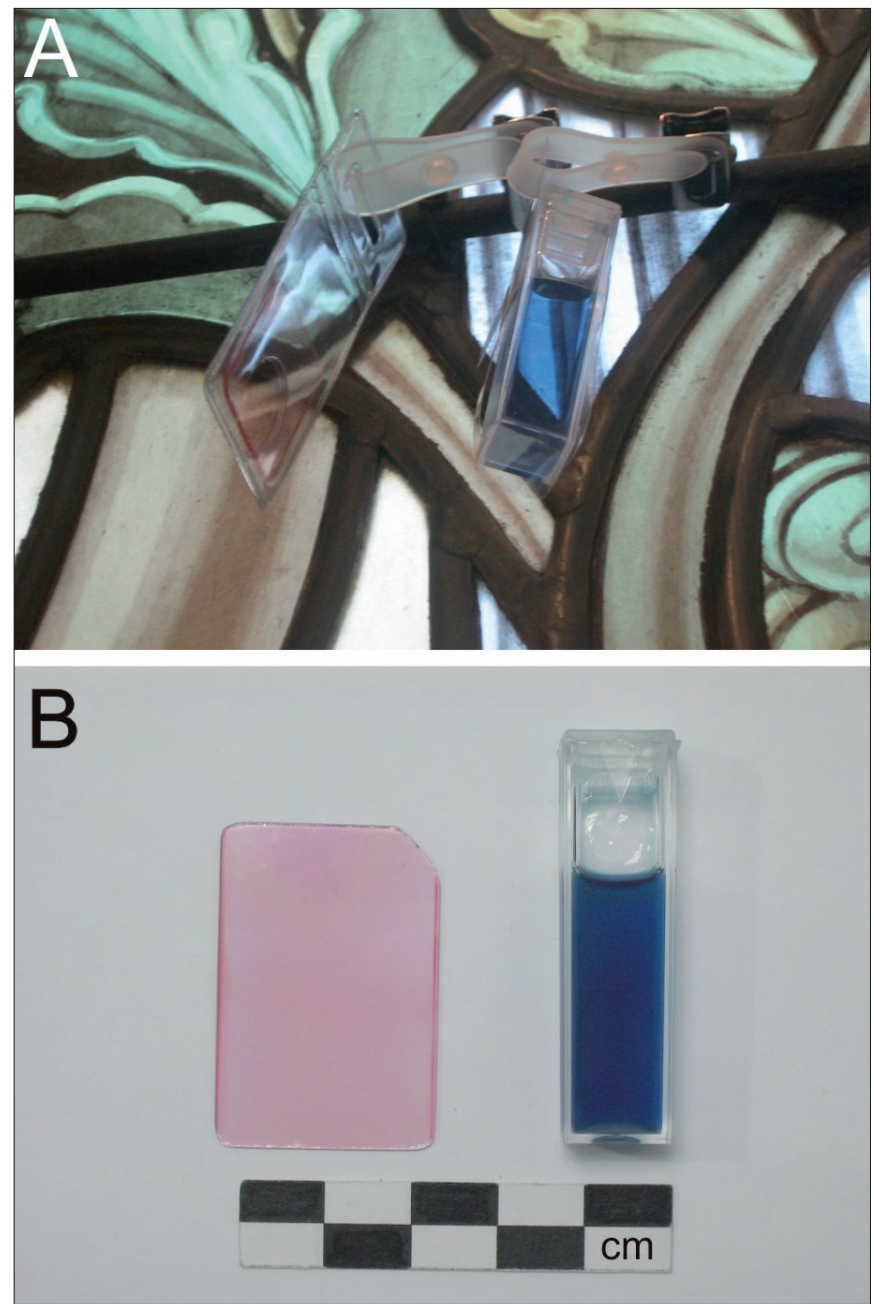

Figure 1. A) Placing of a couple of sensors, one for acidity (left) and another one for temperature (right), at a given indoor position. B) Image showing the look of an acidity sensor (left) and a temperature sensor (right) in the laboratory. left to room temperature for several days to allow further gelification and densification [22].

\subsection{Calibration of sensors}

Both kinds of sensors (acidity and temperature) give an optical response, thereby providing a colour change as a function of the corresponding environmental parameter recorded. Optical absorption spectra of the sensors were measured with an Ocean Optics HR4000 spectrophotometer within the wavelength range from 200 to $1100 \mathrm{~nm}$. A portable and wireless small measurement electronic unit developed by the research team was also used for some in situ field measurements to check its accuracy with respect to conventional measurements accomplished with the spectrophotometer mentioned above. Both the sensors and the measurement unit are protected under patent [21, 23].

Calibration curves of acidity sensors were constructed by measuring the intensity of the absorption band at 575 $\mathrm{nm}$, once the sensors were sensitized in different buffered solutions (Hydrion Buffer Salt, Aldrich). Calibration curves of temperature sensors were undertaken, in turn, by measuring the intensity of the absorption band at 669 $\mathrm{nm}$, once the sensors were sensitized in a climatic test

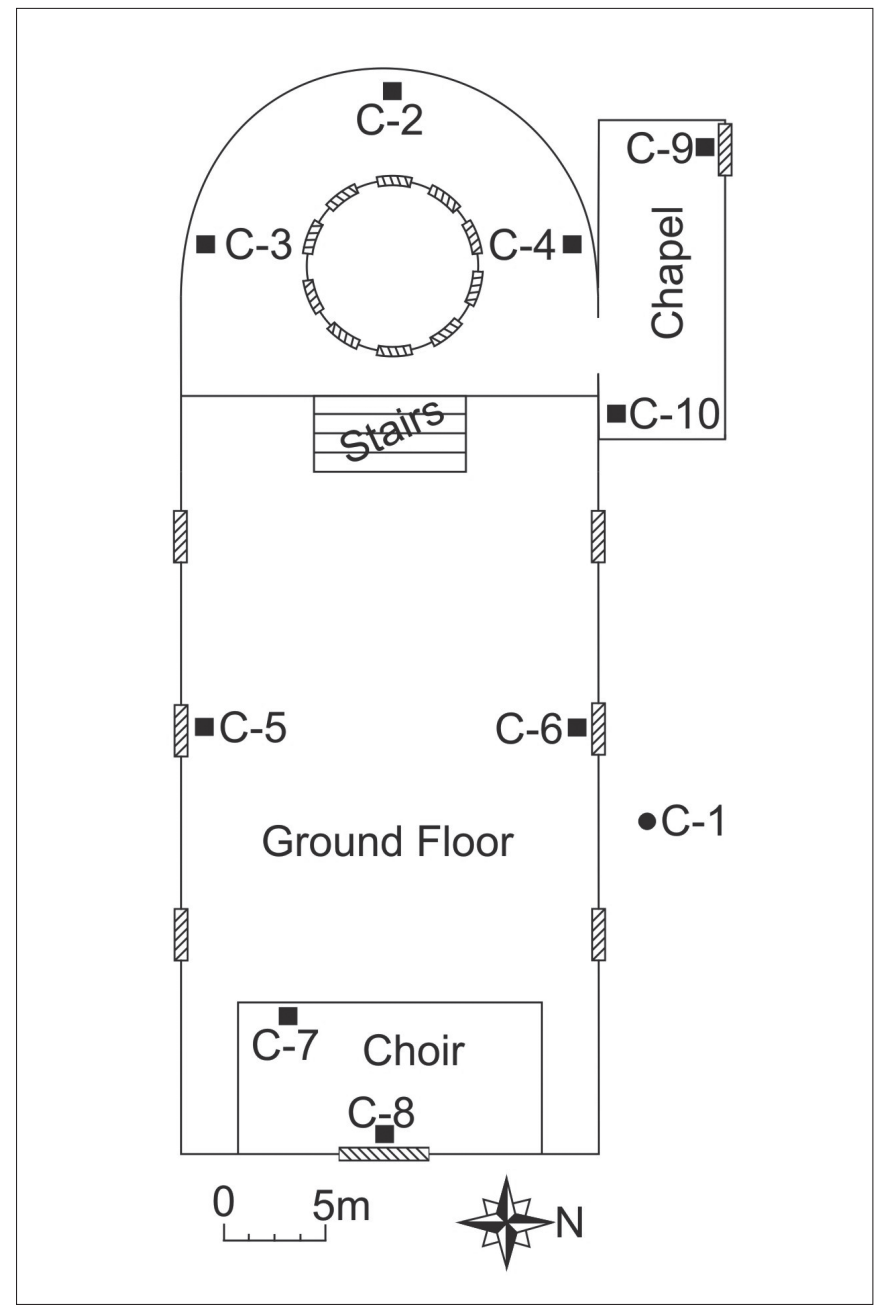

Figure 2. A schematic map showing location of sensors' positions at the Holy Spirit church (approximated scale). Stained glass windows are indicated by dashed rectangles. Black square: indoor position. Black circle: outdoor position. 


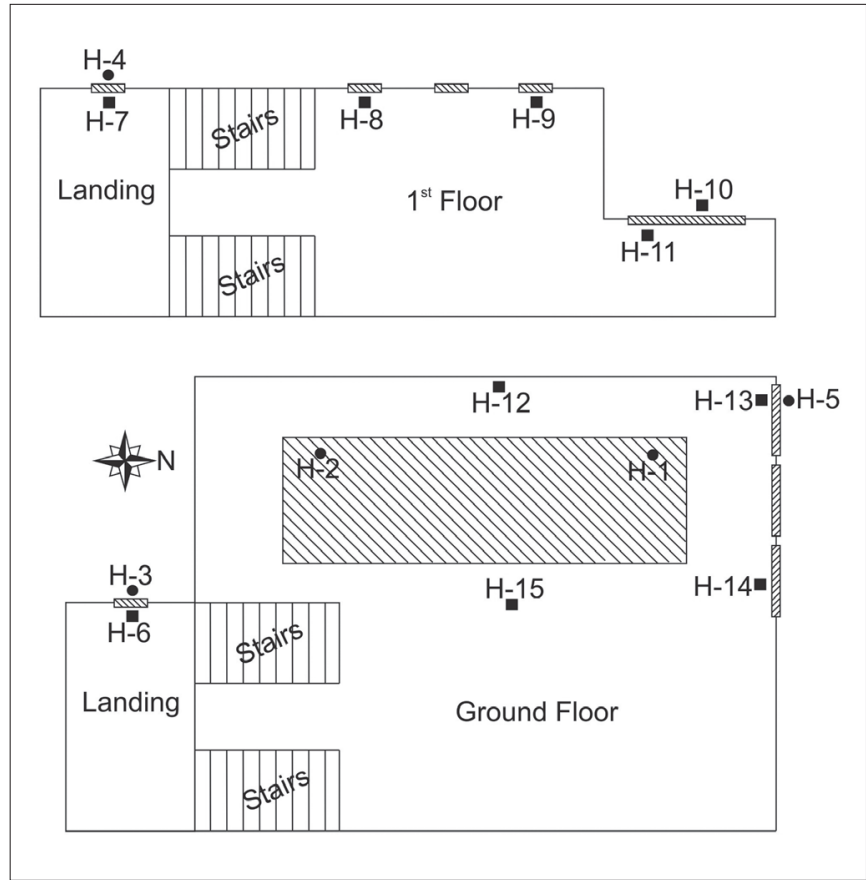

Figure 3. A schematic map showing location of sensors' positions at the CSIC headquarters (approximated scale). Stained glass windows are indicated by dashed rectangles. Black square: indoor position. Black circle: outdoor position.

chamber (Dycometal CCM-25/81) stabilized at different temperatures.

\subsection{Installation of sensors and measurement of their optical response}

Evaluation of environmental conditions through both acidity and temperature sensors was accomplished at two distinct buildings that house stained glass windows from the Mauméjean workshop: the Holy Spirit church and the CSIC headquarters. Both buildings are located at Serrano Street in Madrid. Stained glass windows at the Holy Spirit church were restored in 2009, whereas those at the CSIC headquarters have never been restored before. By means of this study information on both general as well as particular adjoining micro-environmental conditions to which these stained glass windows are subjected, has been gathered. Several representative positions, both indoor and outdoor at the two buildings, were selected following those criteria used by some authors in other historic buildings [24,25]. A couple of sensors, one for acidity and another one for temperature, was placed in each position as is shown in Figure 1. Figure 2 displays position of sensors at the Holy Spirit church. Indoor temperature sensors were placed in symmetrically similar positions to evaluate possible temperature fluctuations inside the temple. Figure 3 shows position of sensors at the CSIC headquarters. Sensors placed at the church were named with a capital $C$ followed by a dash and a correlative number, whereas those placed at the headquarters were named with a capital $H$, a dash, and the corresponding correlative number. Descriptive information of each sensor position is summarised in Table 1 for sensors placed at the Holy Spirit church and in Table 2 for those placed at the CSIC headquarters.
TABle 1. Descriptive Information OF SENSORS' POSITIONS AT THE Holy SPIRIT CHURCH.

\begin{tabular}{|c|l|}
\hline Position & \multicolumn{1}{|c|}{ Description } \\
\hline C-1 & Outdoor position facing North (c 10 m in height) \\
\hline C-2 & Behind the high altar \\
\hline C-3 & Left of the high altar \\
\hline C-4 & Right of the high altar and close to the chapel access \\
\hline C-5 & Close to the statue of St. Isidore of Seville \\
\hline C-6 & Close to the statue of St. Albert the Great \\
\hline C-7 & Choir level (c 10 $\mathrm{m}$ in height) \\
\hline C-8 & $\begin{array}{l}\text { Indoor side of the stained glass rose window (c } 10 \mathrm{~m} \\
\text { in height) }\end{array}$ \\
\hline C-9 & Indoor side of the stained glass window at the chapel \\
\hline C-10 & Opposite side of the stained glass window at the chapel \\
\hline
\end{tabular}

TABLE 2. DesCriPTIVE INFORMATION OF SENSORS' POSITIONS AT THE CSIC HEADQUARTERS.

\begin{tabular}{|c|l|}
\hline Position & \multicolumn{1}{|c|}{ Description } \\
\hline H-1 & $\begin{array}{l}\text { Protected area from outdoor environmental conditions } \\
\text { at the roof skylight stained glass window }\end{array}$ \\
\hline H-2 & $\begin{array}{l}\text { Exposed area to outdoor environmental conditions at } \\
\text { the roof skylight stained glass window }\end{array}$ \\
\hline H-3 & $\begin{array}{l}\text { Outdoor side of a stained glass window at the ground } \\
\text { floor landing of the stairs }\end{array}$ \\
\hline H-4 & $\begin{array}{l}\text { Outdoor side of a stained glass window at the first } \\
\text { floor landing of the stairs }\end{array}$ \\
\hline H-5 & $\begin{array}{l}\text { Outdoor left side of a stained glass window at the } \\
\text { ground floor }\end{array}$ \\
\hline H-6 & $\begin{array}{l}\text { Indoor side of a stained glass window at the ground } \\
\text { floor landing of the stairs }\end{array}$ \\
\hline H-7 & $\begin{array}{l}\text { Indoor side of a stained glass window at the first floor } \\
\text { landing of the stairs }\end{array}$ \\
\hline H-8 & $\begin{array}{l}\text { Indoor left side of a stained glass window at the first } \\
\text { floor hall }\end{array}$ \\
\hline H-9 & $\begin{array}{l}\text { Indoor right side of a stained glass window at the first } \\
\text { floor hall }\end{array}$ \\
\hline H-10 & $\begin{array}{l}\text { Outdoor side of a stained glass window at the first } \\
\text { floor corridor }\end{array}$ \\
\hline H-11 & $\begin{array}{l}\text { Indoor side of a stained glass window at the first floor } \\
\text { corridor }\end{array}$ \\
\hline H-12 & Behind a statue at the ground floor hall \\
\hline H-13 & $\begin{array}{l}\text { Indoor left side of a stained glass window at the } \\
\text { ground floor }\end{array}$ \\
\hline H-14 & $\begin{array}{l}\text { Indoor right side of a stained glass window at the } \\
\text { ground floor }\end{array}$ \\
\hline H-15 & $\begin{array}{l}\text { Close to a column at the ground floor hall (c 3 m in } \\
\text { height) }\end{array}$ \\
\hline wata & were acouired \\
\hline
\end{tabular}

Data were acquired during 13 consecutive months, and they were recorded with the same spectrophotometer used previously to undertake calibration curves. Spectra were stored on a laptop and processed later using spreadsheet computer applications to calculate $\mathrm{pH}$ and temperature values through the corresponding calibration curves.

\section{RESULTS}

\subsection{Environmental acidity}

The $\mathrm{pH}$ values of the air were obtained from the calibration curve constructed from the optical response of sensors 
(absorbance intensities at $575 \mathrm{~nm}$ ) for different buffered pHs. The fitting equation for the calibration curve within the $\mathrm{pH}$ range from 4 to 8 is a linear function ( $y=0.039 x-0.132)$, which allows determination of $\mathrm{pH}$ values with an associated experimental error of $\pm 0.03 \mathrm{pH}$ units.

On the one hand, average data calculated from all the outdoor positions for the whole evaluation period provided a $\mathrm{pH}$ value of 4.6 at the Holy Spirit church and of 5.0 at the CSIC headquarters. On the other hand, acidity average values calculated from indoor positions at both buildings for the whole evaluation period presented, however, notable differences. The indoor average $\mathrm{pH}$ value at the Holy Spirit church was 6.5, whereas at the CSIC headquarters was 5.6. Difference in indoor acidity is, therefore, of $0.9 \mathrm{pH}$ units.

A characteristic result of the acidity evaluation is the $\mathrm{pH}$ difference or $\mathrm{pH}$ variation $(\Delta \mathrm{pH})$ in a given set of measurements. Thus, the $\Delta \mathrm{pH}$ between indoor and outdoor at the Holy Spirit church is 1.9, whereas at the CSIC headquarters is 0.6. This indicates that the $\mathrm{pH}$ gradient is positive and more intense in the church than in the headquarters. In this latter the overall indoor acidity is more similar to that of outdoor and, hence, more acid in comparison with the indoor acidity of the Holy Spirit church. Accordingly, to carry out adequate conservation tasks of indoor cultural goods at both buildings, indiscriminate ventilation or uncontrolled entrance of outdoor air should be avoided.

Table 3 displays the $\mathrm{pH}$ average values calculated for all indoor and outdoor positions at the Holy Spirit church, whereas Table 4 shows such values calculated from both kinds of positions at the CSIC headquarters.

Another phenomenon concerned with evolution of acidity values can be appreciated in Figure 4. The response of the sensors placed at indoor positions repeatedly shows a decreasing trend from the initial $\mathrm{pH}$ value $(\mathrm{pH}=7.0)$, which corresponds to the moment of their placing. This trend is slowly produced throughout several days until a stable $\mathrm{pH}$ value is reached. The stable value corresponds to the real acidity measured in a given place. This phenomenon could be explained by the low relative humidity present indoor at both buildings (the average relative humidity estimated

TAble 3. Data obtained by Sensors Placed at the Holy Spirit church.

\begin{tabular}{|c|c|c|c|c|c|c|c|c|}
\hline Position & $\begin{array}{c}\text { Average } \\
\text { pH }\end{array}$ & $\begin{array}{l}\text { Maximum } \\
\mathrm{pH}\end{array}$ & $\begin{array}{l}\text { Minimum } \\
\mathrm{pH}\end{array}$ & $\Delta \mathrm{pH}$ & $\begin{array}{c}\text { Average } \\
\mathrm{T}\left({ }^{\circ} \mathrm{C}\right)\end{array}$ & $\begin{array}{l}\text { Maximum } \\
\mathrm{T}\left({ }^{\circ} \mathrm{C}\right)\end{array}$ & $\begin{array}{l}\text { Minimum } \\
\mathrm{T}\left({ }^{\circ} \mathrm{C}\right)\end{array}$ & $\Delta \mathrm{T}\left({ }^{\circ} \mathrm{C}\right)$ \\
\hline \multicolumn{9}{|l|}{ Outdoor } \\
\hline C-1 & 4.63 & 5.48 & 4.30 & 1.18 & 13.32 & 33.52 & 0.53 & 32.99 \\
\hline \multicolumn{9}{|l|}{ Indoor } \\
\hline C-2 & 6.84 & 7.69 & 6.25 & 1.44 & 25.58 & 33.71 & 15.94 & 17.77 \\
\hline$C-3$ & 6.93 & 7.88 & 5.99 & 1.89 & 26.33 & 33.63 & 15.52 & 18.11 \\
\hline$C-4$ & 6.89 & 7.64 & 5.97 & 1.67 & 25.93 & 33.02 & 15.39 & 17.63 \\
\hline$C-5$ & 7.14 & 7.99 & 6.17 & 1.82 & 26.96 & 33.18 & 17.39 & 15.79 \\
\hline$C-6$ & 6.86 & 7.76 & 6.12 & 1.64 & 25.34 & 30.36 & 15.77 & 14.59 \\
\hline$C-7$ & 6.55 & 7.85 & 5.05 & 2.80 & 25.90 & 34.10 & 15.42 & 18.68 \\
\hline C-8 & 5.62 & 7.27 & 4.56 & 2.71 & 26.16 & 35.87 & 14.35 & 21.52 \\
\hline C-9 & 5.42 & 6.43 & 4.76 & 1.67 & 21.94 & 31.26 & 12.25 & 19.01 \\
\hline$C-10$ & 6.27 & 7.40 & 5.48 & 1.92 & 23.91 & 32.30 & 13.90 & 18.40 \\
\hline
\end{tabular}

TABLE 4. DATA OBTAINED by SENSORS PLACED AT THE CSIC HEADQUARTERS.

\begin{tabular}{|c|c|c|c|c|c|c|c|c|}
\hline Position & Average $\mathrm{pH}$ & $\begin{array}{c}\text { Maximum } \\
\mathrm{pH}\end{array}$ & $\begin{array}{c}\text { Minimum } \\
\mathrm{pH}\end{array}$ & $\Delta \mathrm{pH}$ & $\begin{array}{c}\text { Average } \\
\mathrm{T}\left({ }^{\circ} \mathrm{C}\right)\end{array}$ & $\begin{array}{l}\text { Maximum } \\
\mathrm{T}\left({ }^{\circ} \mathrm{C}\right)\end{array}$ & $\begin{array}{l}\text { Minimum } \\
\mathrm{T}\left({ }^{\circ} \mathrm{C}\right)\end{array}$ & $\Delta \mathrm{T}\left({ }^{\circ} \mathrm{C}\right)$ \\
\hline \multicolumn{9}{|l|}{ Outdoor } \\
\hline H-1 & 4.82 & 7.39 & 4.35 & 3.04 & 18.54 & 34.09 & 6.96 & 27.13 \\
\hline $\mathrm{H}-2$ & 4.70 & 6.43 & 4.35 & 2.08 & 14.86 & 32.40 & 2.46 & 29.94 \\
\hline $\mathrm{H}-3$ & 4.53 & 5.88 & 4.28 & 1.60 & 15.92 & 32.98 & 3.08 & 29.90 \\
\hline $\mathrm{H}-4$ & 4.55 & 5.38 & 4.30 & 1.08 & 18.34 & 32.47 & 5.64 & 26.83 \\
\hline H-5 & 4.78 & 6.25 & 4.30 & 1.95 & 15.80 & 32.25 & 3.59 & 28.66 \\
\hline \multicolumn{9}{|l|}{ Indoor } \\
\hline H-6 & 4.96 & 5.53 & 4.51 & 1.02 & 27.16 & 33.60 & 18.28 & 15.32 \\
\hline $\mathrm{H}-7$ & 4.95 & 6.83 & 4.33 & 2.50 & 24.54 & 32.01 & 16.70 & 15.31 \\
\hline H-8 & 5.39 & 7.17 & 4.38 & 2.79 & 26.50 & 33.08 & 18.10 & 14.98 \\
\hline H-9 & 5.33 & 6.71 & 4.64 & 2.07 & 25.05 & 31.77 & 17.89 & 13.88 \\
\hline $\mathrm{H}-10$ & 6.05 & 7.14 & 5.12 & 2.02 & 26.75 & 33.67 & 19.96 & 13.71 \\
\hline $\mathrm{H}-11$ & 5.73 & 6.87 & 5.01 & 1.86 & 26.49 & 33.88 & 19.68 & 14.20 \\
\hline $\mathrm{H}-12$ & 6.27 & 7.05 & 5.60 & 1.45 & 25.60 & 33.30 & 16.12 & 17.18 \\
\hline $\mathrm{H}-13$ & 5.45 & 7.39 & 4.48 & 2.91 & 23.83 & 32.30 & 14.35 & 17.95 \\
\hline $\mathrm{H}-14$ & 5.48 & 7.05 & 4.56 & 2.49 & 23.33 & 33.96 & 13.42 & 20.54 \\
\hline H-15 & 6.18 & 7.15 & 5.15 & 2.00 & 26.80 & 34.55 & 17.61 & 16.94 \\
\hline
\end{tabular}



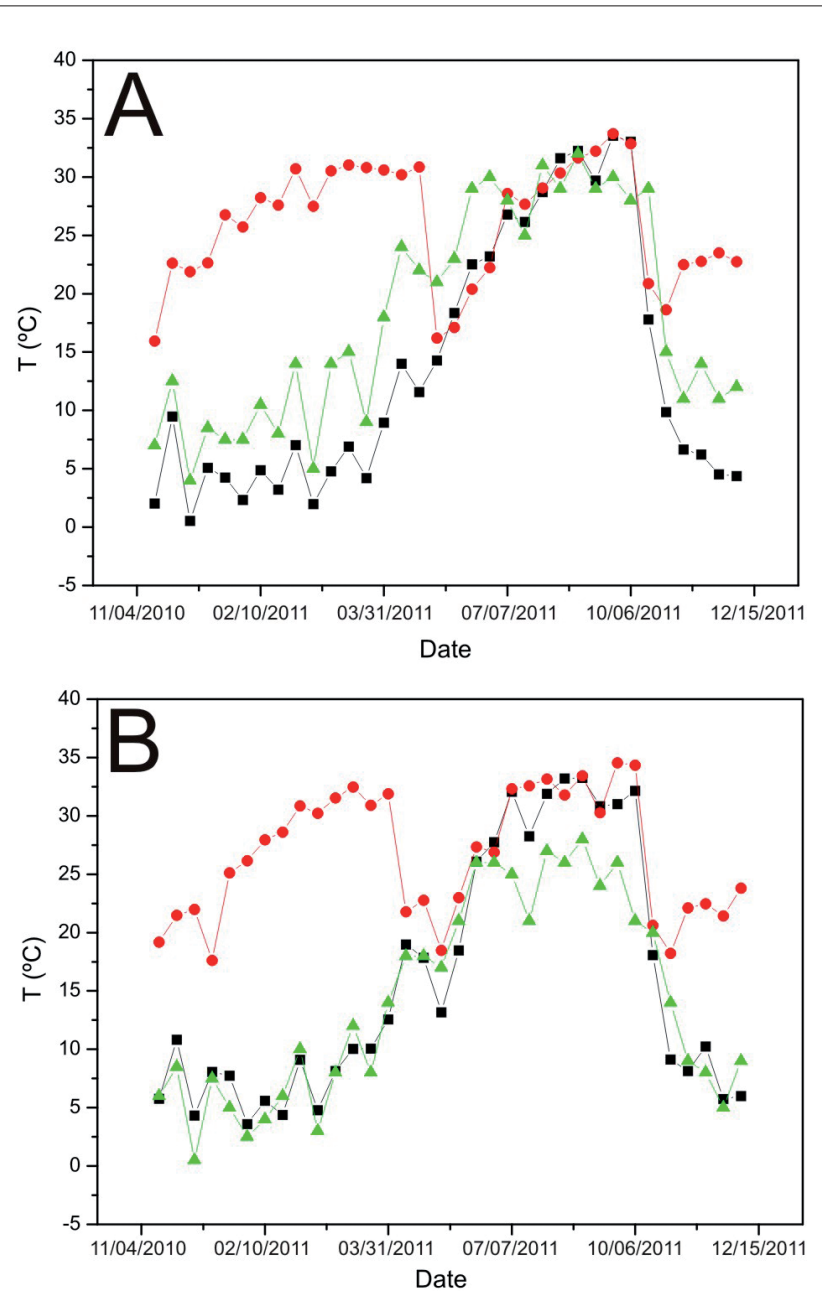

Figure 4. $\mathrm{pH}$ data recorded for the 13 months evaluation undertaken at: A) The Holy Spirit church, indoor position C-9 (circles) and outdoor position C-1 (squares); B) The CSIC headquarters, indoor position H-9 (circles) and outdoor position H-3 (squares).

with a conventional probe was between 30 and $35 \%$ ). To get a fast response of the sensors a higher relative humidity is needed. This occurs, for instance, at outdoor positions, in which the annual average of the relative humidity is $59 \%$ according to data provided by the Spanish National Agency of Meteorology (AEMET), for a thirty year period recorded by a nearby meteorological station. The evolution of sensors to reach stable acidity data (real values) is therefore faster at outdoor positions.

Environmental acidity data were also recorded for 4 months (in the middle of the whole evaluation period) with the portable and wireless small electronic unit developed by the research team [21,23]. This device is able to record the colour (optical absorption) of the sensors once sensitized, and to store the corresponding value in $\mathrm{mV}$. These data were then wirelessly transmitted to a laptop to calculate $\mathrm{pH}$ values through the corresponding calibration curve [26]. Acidity data recorded by this procedure showed some variations in comparison with regular data acquired through the spectrophotometer mentioned above in the methodology section. For instance, such variations ranged from 0.02 to 0.80 $\mathrm{pH}$ units at the Holy Spirit church, whereas they ranged from 0.08 to $1.60 \mathrm{pH}$ units at the CSIC headquarters. Differences of $\mathrm{pH}$ values measured by each instrument are too high and indicate a low reliability of the portable device in its present state. Consequently, device electronics must be improved and data recorded up to now must be considered as a first approach to the commissioning of a very useful portable and wireless small device to record in situ field $\mathrm{pH}$ values.

\subsection{Environmental temperature}

The temperature values were obtained from the calibration curve constructed from the optical response of sensors (absorbance intensities at $669 \mathrm{~nm}$ ) for different temperatures ranging from $0{ }^{\circ} \mathrm{C}$ to $35^{\circ} \mathrm{C}$. The fitting equation for the calibration curve within this range is a polynomial function $\left(y=0.001 x^{2}+0.033 x+0.435\right)$, which allows determination of temperature values with an associated experimental error of \pm 0.02 Celsius degrees.

Table 3 displays temperature average values at each position for the whole evaluation period, as well as maximum and minimum values recorded at the Holy Spirit church. Likewise, Table 4 shows the respective values taken at the CSIC headquarters. Whole average values indoor both buildings are approached to $25.5^{\circ} \mathrm{C}$, even though local average temperatures from $22^{\circ} \mathrm{C}$ to $27^{\circ} \mathrm{C}$ were recorded. As expected, outdoor average temperature results at both buildings were lower than indoor ones. Average temperature at the Holy Spirit church was $13.3^{\circ} \mathrm{C}$, whereas that obtained at the CSIC headquarters was $16.7^{\circ} \mathrm{C}$.

\section{DISCUSSION}

The small difference between the $\mathrm{pHs}$ recorded outdoor the two buildings (4.6 at the Holy Spirit and 5.0 at the CSIC headquarters) could be explained by the church location in the own Serrano Street with heavy road traffic. In turns, the CSIC headquarters are located $200 \mathrm{~m}$ from this street, in a recess which forms an open courtyard. Proximity of road traffic favours a higher concentration of gaseous pollutants in the environment coming from combustion of vehicles. This increases the concentration of acid substances detected by the sensors placed outdoor of the church.

However, the average $\mathrm{pHs}$ recorded indoor are very different for the two buildings (6.5 at the Holy Spirit and 5.6 at the CSIC headquarters). This variation could be due to distinct functionality of buildings. The Holy Spirit church remains closed when religious ceremonies are not taking place, whereas the CSIC headquarters is a public building which remains open during working hours and supports an intense move of personnel. The CSIC headquarters building is therefore more ventilated with outdoor air and, consequently, receives a higher incidence of urban and human interaction pollutants. These variables may give rise to a more pronounced acidity.

Environmental pH results of the Holy Spirit church (Table 3) present the closest values to theoretical neutral conditions $(\mathrm{pH}=7.0)$. However, resulting data from positions C-8 and C-9 show quite separated values from neutrality, namely 5.6 and 5.4, respectively. In these two positions the sensors were placed very near to the internal side of two different stained glass windows. Filtration and/or partial ventilation favoured by the own stained glass window could explain why these values are lower (more acid) than those recorded at other indoor places of the church. This phenomenon can be also 
assigned to the $\mathrm{pH}$ values recorded in the following indoor positions at the CSIC headquarters: H-6, H-7, H-8, H-9, H-13, and $\mathrm{H}-14$ (Table 4). In these positions, the $\mathrm{pH}$ average value is around 5.3.

As mentioned above, stained glass windows at the Holy Spirit church were restored in 2009. With the purpose of preserving the stained glass windows of urban environmental weathering, a conventional protective glazing system was installed. Such a system guarantees their isolation against wind pressure, rain, bird droppings, vandalism, and so on. Nevertheless, $\mathrm{pH}$ values recorded at those places adjoined to the indoor side of stained glass windows of both buildings, restored or non-restored, are very similar, which indicate that protective glazing systems do not prevent filtration of the outdoor air and pollutants that this air may contain. In any case, it is important to note that international committees have pointed out these protective glazing systems as one of the most effective methods to preserve glasses and other materials of historic stained glass windows [27,28]. These protective glazing are not hermetically sealed to favour natural circulation of air and to avoid condensations, which may cause the hydrolytic attack on either some parts of the glass surface or the glassy paint layers (grisailles) applied on its surfaces.

As concerns $\mathrm{pH}$ data recorded by using the portable wireless device, designed and produced to measure the sensors' optical response in situ, several reasons could explain their low accuracy. In fact, differences between $\mathrm{pH}$ data recorded with the spectrophotometer respect to those recorded with the portable device, for a same sensor position, should be attributed to the electronic construction of the device. Firstly, it should be provided with an appropriate electronic component to compensate temperature variations, since such variations (for instance from indoor to outdoor, during the data recording) may modify the electrical response of LED's, photodiodes, microprocessor, etc. Other improvement could be the incorporation of another calibration curve based on the characteristic absorption band of sensors at $430 \mathrm{~nm}$, approximately. Such a band is less intense than that at $575 \mathrm{~nm}$ currently used for the construction of the present calibration curve, but it shows higher reliability and, probably, will diminish the associated absolute error. Finally, the incorporation of an external relative humidity probe would provide to the portable device an additional information source that will make easier the data interpretation.

The difference between local average temperature values (see Tables 3 and 4) recorded indoor the Holy Spirit church and the CSIC headquarters, are mainly due to different locations of the sensors. For instance, some sensors were located near to a heat source (positions C-5 and H-6); other sensors were placed at the indoor side of a stained glass window which faced East and, consequently, the sun incises directly on it, thereby causing an overheating (position C-8); while other ones were situated at the indoor side of stained glass windows facing North (positions C-9, H-13, and H-14). Sensors from positions C-5 and C- 6 were placed indoor the main nave of the temple. Position C-5 was located on the left and close to a grid of the heating system and position C-6 was situated on the opposite side at a place separated from the heating elements. Resulting data showed that heating determines a higher annual average temperature in position C-5 than in position C-6. Sensors from positions C-9 and C-10 were placed indoor the Chapel of the Immaculate Virgin Mary, on the internal side of the corresponding stained glass window and on the opposite wall of the chapel, respectively. Average temperature measured from position C-9 was lower than that recorded from position C-10. This is easily explained by the small outdoor air draughts filtered through the stained glass window since, as mentioned earlier, they do not have a hermetic sealing.

The noticeable difference between the average temperature values (see Tables 3 and 4) recorded outdoor the two buildings in close proximity can be justified by the methodology employed. Due to technical reasons such as limited accessibility and height of the church building, outdoor temperature evaluation at the Holy Spirit church was recorded by a unique position which faced North. In contrast, outdoor temperature at the CSIC headquarters was recorded by 5 positions with different orientations. In addition, in case of headquarters, high temperatures measured in some outdoor positions were particular rather than representative. For instance, the average outdoor temperature value $\left(18.3^{\circ} \mathrm{C}\right)$ taken from the sensor placed at position $\mathrm{H}-4$, was due to the sunlight incised directly on a stained glass window which faced West. A similar case occurs in positions $\mathrm{H}-1$ and $\mathrm{H}-2$, which were placed at the roof skylight stained glass windows from the CSIC headquarters. These latter sensors are protected by the external and partially closed cover of the roof skylight stained glass windows, which gives rise to relatively high temperatures with respect to the real outdoor ones. The sensor of position $\mathrm{H}-2$ was close to the non-covered lateral side and, consequently, it presented a lower annual average temperature than that recorded by position $\mathrm{H}-1$, which was placed on the opposite site at a closed area.

Sensors from positions $\mathrm{H}-3$ and $\mathrm{H}-4$ displayed different average temperatures $\left(15.9{ }^{\circ} \mathrm{C}\right.$ and $18.3^{\circ} \mathrm{C}$, respectively), in spite of they were installed at a vertical distance of less than $5 \mathrm{~m}$. These sensors were placed on the external side of two stained glass windows facing West. These windows are located in two landings of the main stairs at the CSIC headquarters. Direct sunlight affected only the upper window and, for this reason, average temperature from position $\mathrm{H}-4$ was higher than that from position $\mathrm{H}-3$. The effect of heating radiators located close to the stained glass windows of both landings was investigated through indoor positions H-6 and H-7. Position H-6 was placed as close as possible to heating radiators, whereas position $\mathrm{H}-7$ was situated on the opposite side far away from that heat source. As expected, annual average temperature recorded by position $\mathrm{H}-7$ was lower than that measured by position $\mathrm{H}-6\left(24.5^{\circ} \mathrm{C}\right.$ and $27.2^{\circ} \mathrm{C}$, respectively).

Tables 3 and 4 also show maximum and minimum temperature values recorded and the net variation of temperature $(\Delta T)$ at each position. Results of $\Delta T$ are useful to estimate risks due to sharp changes of temperature. Average values of $\Delta \mathrm{T}$ indoor the church and the headquarters are $18{ }^{\circ} \mathrm{C}$ and $16{ }^{\circ} \mathrm{C}$, respectively. This variation could be dangerous for conservation of stained glass windows and their materials. However, as the variation occurs gradually all the year around, it does not involve a sharp change of temperature. In Figure 5 it can be appreciated that overall temperature variations are gradual rather than sharp, which means that they can not be considered dramatically dangerous for conservation of stained glasses and other inorganic materials. Nevertheless, two 

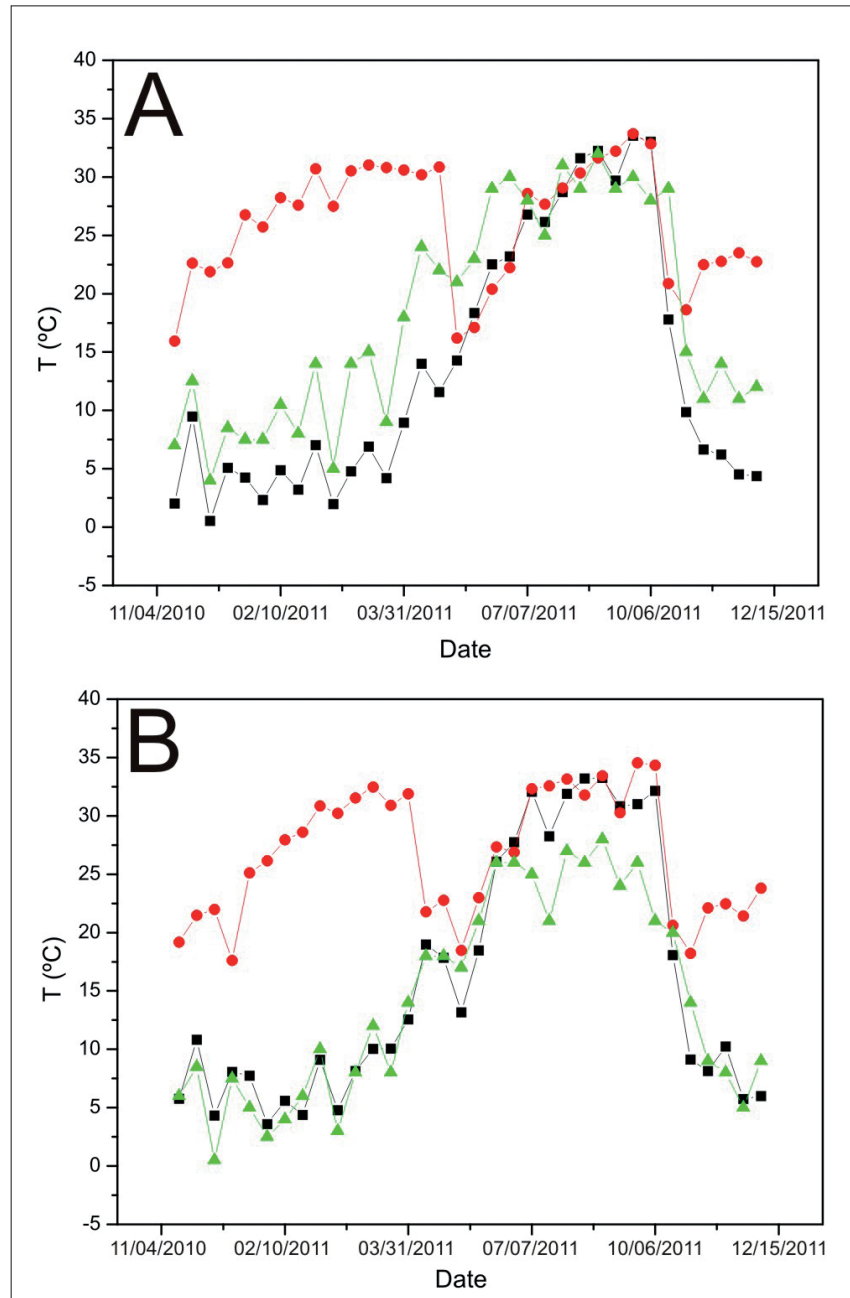

Figure 5. Temperature data recorded for the 13 months evaluation undertaken at: A) The Holy Spirit church, indoor position C-2 (circles) and outdoor position C-1 (squares); B) The CSIC headquarters, indoor position H-15 (circles) and outdoor position H-5 (squares). Reference average temperature data (triangles) taken from the Spanish National Agency of Meteorology (AEMET) are included. Temperatures from the Holy Spirit church were recorded at $12 \mathrm{pm}$ and those from the CSIC headquarters at $10 \mathrm{am}$.

important and noticeable situations can be observed. The first one was produced in April and shows an indoor temperature drop of $10{ }^{\circ} \mathrm{C}$, which is due in all probability to the end of the heating season. The second one was produced in October and is certainly connected with the outdoor temperature drop of beginning of the fall and coming into operation of the heating system. Considerable and sharp variations of temperature occurred in both situations, which could contribute negatively to conservation of stained glass windows. Particularly, they could cause deterioration of glass fragments and lead cames, since mechanical problems may arise due to the different expansion coefficients of these materials. It should be advised that the heating system came into operation and shutdown gradually to avoid such sharp temperature variations and to guaranty the thermal quality of the building [1].

Finally, outdoor temperatures at both buildings show annual variations close to $30^{\circ} \mathrm{C}$, which can be interpreted by seasonal changes. Some outdoor positions display, however, lower annual variations, such as positions $\mathrm{H}-1$ and $\mathrm{H}-4$ $\left(18.5^{\circ} \mathrm{C}\right.$ and $18.3^{\circ} \mathrm{C}$, respectively). These values can be explained because sensors were partially protected by the cover, as is the case of position $\mathrm{H}-1$; or directly affected by the sunlight, as position $\mathrm{H}-4$. The drop in temperature was cushioned in both cases in comparison with sensors placed at other less protected positions.

\section{CONCLUSIONS}

An innovative sol-gel sensing technology has been successfully applied to assess the impact of urban pollution in the conservation of Mauméjean stained glass windows from two heritage buildings. Thus, sol-gel based novel optical sensors of environmental acidity and temperature have proved to be very effective at evaluating conservation conditions of historic stained glass windows, either restored or non-restored, subjected to common pollutant sources of a modern city. Evaluation of such conditions is a key factor to establish appropriate mid and long-term preventive conservation strategies.

Atmospheric neutral conditions move towards an acid environment as the source of pollutants (mainly road traffic) is nearer. The technology of sol-gel optical environmental sensors here developed is able to determine and discriminate outdoor $\mathrm{pH}$ differences caused by heavy road traffic in distances of less than $200 \mathrm{~m}$. In addition, $\mathrm{pH}$ changes due to indoor/outdoor location, façade orientation, position, and human interaction with the building have been also recorded by this kind of sensors.

It has been verified that the use of non-hermetic glazing protective systems, which avoid condensation phenomena and, accordingly, hydrolytic attack on glass surface, do not completely isolate both sides of stained glass windows from acid pollutants and therefore from low and dangerous $\mathrm{pH}$ environments.

The environmental $\mathrm{pH}$ data obtained by using a portable measuring device, designed and produced ad hoc, have low accuracy compared with the corresponding data recorded with a spectrophotometer. Consequently, some improvements are needed concerning its electronic components, its calibration curve and additional environmental probes.

\section{Acknowledgements}

The authors are deeply indebted to the Subdirección General de Obras e Infraestructuras (CSIC, María del Carmen González Peñalver), the Servicio de Patrimonio (CSIC, José Antonio Ocaña Martínez) and the Holy Spirit church Rectorate, for providing official permissions, access, and kind cooperation. They acknowledge partial funding of the research program Geomateriales (ref. CM S-2009/Mat-1629, Regional Government of Madrid). Finally, the authors wish to mention the professional support of the Spanish TechnoHeritage network.

\section{BIBLIOGRAPHY}

1. Corgnati, S.P.; Fabi, V.; Filippi, M. (2009): A methodology for microclimatic quality evaluation in museums: Application to a temporary exhibit, Building and Environment, 44: 1253-1260.

2. Pavlogeorgatos, G. (2003): Environmental parameters in museums, Building and Environment, 38: 1457-1462. 
3. Ng, L.C.; Musser, A.; Persily, A.K.; Emmerich, S.J. (2012): Indoor air quality analyses of commercial reference buildings, Building and Environment, 58: 179-187.

4. Saraga, D.; Pateraki, S.; Papadopoulos, A.; Vasilakos, Ch.; Maggos, Th. (2011): Studying air quality in three non-residencial environments of different use: A museum, a printery industry and an office, Building and Environment, 46: 2333-2341.

5. Römich, H.; Dickmann, K.; Mottner, P.; Hildenhagen, J.; Muller, E. (2003): Laser cleaning of stained glass windows. Final results of a research project, J. Cult. Herit., 4 (Supplement 1): 112-7.

6. Müller, W. (1992): Corrosion phenomena of Medieval stained glasses, Bol. Soc. Esp. Ceram. V., 31-C (1): 219-239.

7. Leissner, J. (1996): The effect of corrosion on stained glass windows, Mater. Construcc., 46 (242-243): 27-38.

8. García-Heras, M.; Carmona, N.; Gil, C.; Villegas, M.A. (2005): Neorenaissance/Neobaroque stained glass widows from Madrid: a characterisation study on some panels signed by the Mauméjean Fréres Company, J. Cult. Herit., 6 (2): 91-8.

9. Carmona, N.; Villegas, M.A.; Fernández Navarro, J.M. (2006): Characterisation of an intermediate decay phenomenon of historical glasses, J. Mater. Sci., 41 (8): 2339-2346.

10. Lombardo, T.; Loisel, C.; Gentaz, L.; Chabas, A.; Verita, M.; Pallot-Frossard, I. (2010): Long term assessment of atmospheric decay of stained glass windows, Corr. Eng. Sci. Technol., 45 (5): 420-4.

11. García-Heras, M.; Gil, C.; Carmona, N.; Villegas, M.A. (2003): Weathering effects on materials from historical stained glass windows, Mater. Construcc., 53 (270): 21-34

12. García-Heras, M.; Villegas, M.A.; Cano, E.; Cortés-Pizano, F.; Bastidas, J.M. (2004): A conservation assessment on metallic elements from Spanish Medieval stained glass windows, J. Cult. Herit., 5 (3): 311-7.

13. Carmona, N.; Villegas, M.A.; Fernández Navarro, J.M. (2006): Study of glasses with grisailles from historic stained glass windows of the Cathedral of León (Spain), Appl. Surf. Sci., 252(16): 5936-5945.

14. García-Heras, M.; Kromka, K.; Faber, J.; Karaszkiewicz, P.; Villegas, M.A. (2005): Evaluation of air acidity through optical sensors, Environmental Sci. Technol., 39 (10): 3743-7.

15. García-Heras, M.; Gil, C.; Carmona, N.; Faber, J.; Kromka, K.; Villegas, M.A. (2005): Optical behaviour of $\mathrm{pH}$ detectors based on sol-gel technology, Anal. Chim. Acta, 540 (1): 147-152.
16. Carmona, N.; Bouzas, V.; Jiménez, F.; Plaza, M.; Pérez, L.; García, M.A. Villegas, M.A.; LLopis, J. (2010): J. Cobalt (II) environment characterization in sol-gel thermochromic sensors, Sensor Actuat. B-Chem, 145 (1): 139-145.

17. Nieto Alcaide, V. (1998): La vidriera española. Ocho siglos de luz, Ediciones Nerea, Madrid, España.

18. García Heras, M.; Fernández Navarro, J.M.; Villegas, M.A. (2012): Historia del vidrio. Desarrollo formal, tecnológico y científico. PIE-CSIC 200460E594, Madrid, España.

19. García Cuellar, F. (2007): La obra artística de Fisac, Adsuara y Stolz en la Iglesia del Espíritu Santo. Editorial CSIC, Madrid, España.

20. Hench, L.L.; West, J.K. (1990): The sol-gel process, Chem. Rev., 90: 33-72.

21. Villegas, M.A.; García Heras, M.; Peña Poza, J.; Arcas Castro G. de; Barrera López de Turiso, E.; López Navarro, J.M.; LLorente Alonso, A. (2010): Sistema para la determinación de acidez ambiental y método que hace uso del mismo, Patente española ref. P201031071. Propietarios: CSIC y UPM.

22. Carmona, N.; Herrero-Hernández, E.; Llopis, J.; Villegas, M.A. (2008) Novel sol-gel reversible thermochromic materials for environmental sensors, J. Sol-Gel Sci. Technol., 47(1): 31-7.

23. Llorente-Alonso, A.; Peña-Poza, J.; Arcas, G. de; García-Heras, M.; López J.M.; Villegas, M.A. (2013): Interface electronic system for measuring air acidity with optical sensors, Sensor Actuat A-Phys., 194: 67-74.

24. Herráez, J.A. (1999): Técnicas y procedimientos de conservación preventiva. Medición y control de los factores del medio: temperatura, humedad relativa, luz, calidad del aire. IPCE, Madrid, España.

25. Peña-Poza, J · García-Heras, M. Palomar, T * Laudy, A · Modzelewska, E. Villegas, M.A. (2011): Environmental evaluation with chemical sensors in the Palace Museum of Wilanów (Warsaw, Poland), Bull. Polish Acad. Sci.: Technical Sciences, 59 (3): 247-252.

26. Llorente-Alonso, A.; Pérez-Lobato, J.; Peña-Poza, J.; Arcas, G. de; Villegas, M.A. (2011): Sistema electrónico para la evaluación de la acidez ambiental con sensores ópticos, Acta Científica y Tecnológica, 19: 24-9.

27. Corpus Vitrearum Guidelines for the Conservation and Restoration of Stained Glass (2004): Colloquium in Nuremberg. Nuremberg: International Committee for the Conservation of Stained Glass.

28. Reilly, S.; Gilberg, M. (2002): Analyzing the impact of protective glazing on stained glass windows, Studies in Conservation, 47 (3): 161-174.

Recibido: 01/08/2013

Recibida versión corregida: 18/10/2013

Aceptado: 28/10/2013 